\title{
PEMANFAATAN INFORMASI BERDASARKAN PORTER'S FIVE FORCES DALAM BISNIS FABRIKASI BAJA UNTUK MENDAPATKAN KEUNGGULAN BERSAING
}

\author{
Kristiawan Hengki Kusuma 1), Januar Budiman 2)
}

\begin{abstract}
ABSTRAK: Saat ini perusahaan fabrikasi baja telah menyadari pentingnya penggunaan informasi sebagai sebuah tools baru untuk mendapatkan keunggulan bersaing dengan kompetitor. Namun sayangnya penggunaan informasi ini masih diterapkan secara konvensional, yaitu penggunaan informasi yang hanya terbatas pada penggunaan IT, tanpa menyadari sebenarnya penggunaan informasi masih menyimpan banyak potensi besar jika digunakan secara optimal.

Penggunaan Informasi yang "asal pakai" tidak hanya kurang efektif namun juga seringkali menimbulkan permasalahan baru. Hasil penyajian data yang diolah oleh orang IT seringkali tidak sesuai dengan tujuan yang ingin dicapai oleh manajemen perusahaan karena perbedaan penafsiran, adapun hasil pengolahan data seringkali juga dapat menimbulkan kesalahpahaman antar pihak manajemen.

Pada penelitian ini akan dicoba pemanfaatan Informasi dengan menggunakan bantuan Porter's Five Forces sebagai alat bantu untuk mendapatkan keunggulan bersaing. Akan dijelaskan juga bagaimana cara untuk mengumpulkan informasi apa saja yang ada di dalam business process yang dibutuhkan dalam perusahaan dan bagaimana cara mengolah data ini menjadi keunggulan bersaing bagi perusahaan fabrikasi.
\end{abstract}

Kata kunci: fabrikasi baja, informasi, keunggulan bersaing, porter's five forces, business process

ABSTRACT: Nowadays, steel fabricator has realized the importance of the use of information as a new tools to gain the competitive advantages with competitors. Unfortunely the use odf the information is still applied in an unconventional manner, the use of information are limited only to $I T$, without realizing actual use information has a lot of great potential if used optimally. The "reckless" use of information was not only less effective but also often lead to new problems. The result of data processed by ITs, usually are not in line with the purpose to be achieved by company management due the differences in the interpretation of the concept, and as for the results of data processing can also cause misunderstanding between management.

On this research will try the utilization of information by using Porter's Five Forces as the tools to gain the competitive advantages. It will be explained also how to collect all information in business process that required in company and how to process this data to be competitive advantages for steel fabrication company.

Key words: steel fabrication, information, competitive advantages, porter's five forces, business process

\footnotetext{
1) Mahasiswa Pasca Sarjana Program Magister Teknik Sipil Universitas Kristen Petra, hangq88@yahoo.com

2) Dosen Pasca Sarjana Program Magister Teknik Sipil Universitas Kristen Petra.

jn.2500@yahoo.com
} 


\section{PENDAHULUAN}

Seperti halnya proyek konstruksi lain, proyek konstruksi baja juga terdiri dari empat aspek penting, yaitu biaya, waktu, kualitas dan keselamatan kerja. Pada dasarnya persaingan dari bisnis dalam fabrikasi baja hanya terpusat pada kualitas hasil pekerjaan, efisiensi biaya dan juga kreatifitas manajemen.

Saat ini perusahaan fabrikasi baja telah menyadari pentingnya penggunaan informasi sebagai sebuah tools baru untuk mendapatkan keunggulan bersaing dengan competitor. Namun sayangnya penggunaan informasi ini masih diterapkan secara konvensional, yaitu penggunaan informasi yang hanya terbatas pada penggunaan IT dimana penggunaan IT disini juga terbatas dengan memperkerjakan orang IT untuk mengolah data.

Padahal sebenarnya penggunaan Informasi yang "asal pakai" ini tidak hanya kurang efektif namun juga seringkali menimbulkan permasalahan baru. Hasil penyajian data yang diolah oleh orang IT seringkali tidak sesuai dengan tujuan yang ingin dicapai oleh management perusahaan karena perbedaan konsep dan penafsiran, adapun hasil pengolahan data seringkali juga dapat menimbulkan kesalahpahaman antar pihak management. Kesalahpahaman diakibatkan oleh penyajian informasi yang tidak tepat sasaran sehingga pembacaan informasi dilakukan secara intuitif oleh pihak perusahaan yang terdiri dari masingmasing level management.

Penggunaan informasi seharusnya mendukung tujuan utama dari sebuah perusahaan yaitu untuk menciptakan keunggulan bersaing dengan competitor, sebuah tujuan membutuhkan beberapa informasi, dan sebuah informasi membutuhkan beberapa data dan sebuah data dapat menghasilkan banyak informasi. Banyaknya data yang dicapture inilah yang harus dapat disajikan dan diterima oleh keyperson dalam data collection maupun pemakai informasi. Setiap level management mempunyai kebutuhan akan informasi yang berbeda dan setiap individu mempunyai intuisi untuk menerima sebuah informasi dengan berbeda, hal ini tentunya akan menimbulkan kesulitan dan tantangan dalam penerapan informasi dalam sebuah perusahaan fabrikasi baja.

Kesulitan yang sering dihadapi oleh perusahaan fabrikasi baja dalam penggunaan Informasi yaitu mencari Informasi apa yang benar-benar diperlukan dan bagaimana menyajikan Informasi tersebut dalam setiap level management menjadi sebuah keunggulan bersaing. Informasi ini berasal dari banyak data, dan data ini harus dapat meng capture semua Informasi yang menggambarkan business environtment dalam perusahaan fabrikasi baja.

Pada penelitian ini akan dicoba pengaplikasian Porter's Five Forces sebagai alat bantu untuk mengumpulkan informasi apa saja yang dibutuhkan dalam perusahaan dan bagaimana cara mengolah data ini menjadi sebuah semantic model bagi perusahaan fabrikasi baja untuk diolah menjadi competitive advantages. Perusahaan akan menyadari besarnya kekuatan Informasi dengan penguasaan akan factor-faktor yang ada di dalam Porter's Five Forces yaitu persaingan antar rival industri, supplier, customer, pendatang baru dan pemain pengganti produk (Porter, 1998).

Melalui penelitian ini, tidak hanya dijelaskan bagaimana penggunaan Informasi dapat menjadi potensi sebagai competitive advantages dengan mengetahui kekuatan-kekuatan yang mempengaruhi dalam persaingan dalam industri, dengan mempersiapkan suatu perusahaan fabrikasi baja melakukan analisis terhadap informasi apa saja yang akan dibutuhkan sebuah perusahaan, namun juga bagaimana perusahaan tersebut mengumpulkan data, mengolah data dan menyajikan data yang ada dalam business process perusahaan fabrikasi baja menjadi informasi yang berguna untuk menekan ke lima faktor yang ada dalam Porter's Five Forces sehingga dapat menjadi keunggulan bersaing. 


\section{METODOLOGI PENELITIAN}

Metode penelitian yang dilakukan dengan mencoba mengaplikasikan penggunaan Informasi dalam perusahaan, dengan menentukan terlebih dahulu keunggulan bersaing (Competitive Advantages) yang ingin dicapai oleh perusahaan fabrikasi baja. Dari berbagai keunggulan bersaing ini kemudian diklasifikasi menjadi 5 bagian besar berdasar factor-faktor yang mempengaruhi persaingan dalam industry yang terdapat dalam Porter Five Forces. Dari lima keunggulan bersaing yang sudah diklasifikasi, diimplementasikan Informasi kedalamnya untuk mendapatkan tujuan utama yaitu memperoleh keunggulan bersaing.

Setiap informasi dapat membutuhkan beberapa data, dan setiap data dapat menghasilkan banyak informasi. Data sendiri dapat berupa informasi, namun data adalah informasi dengan bagian terkecil yang terkait langsung dengan sebuah kerjadian atau proses.

Metodologi yang digunakan dalam penelitian ini:

1. Untuk mendapatkan Competitive Advantages maka perusahaan harus menentukan terlebih dahulu informasi apa yang akan digunakan. Pada penelitian ini akan digunakan tiga contoh informasi yaitu informasi mengenai mutu (Quality), efisiensi (Eficiency) dan waktu (time)

2. Dari ke tiga macam informasi yang digunakan akan dicari entity dari masing masing informasi, entity pada penelitian ini dibagi menjadi Project, Resources, Workpackage dan Bill of Quantity. Pemilihan ke empat entity ini dianggap sudah mewakili keseluruhan item yang terlibat dalam sebuah business process seperti terlihat pada Gambar 1.

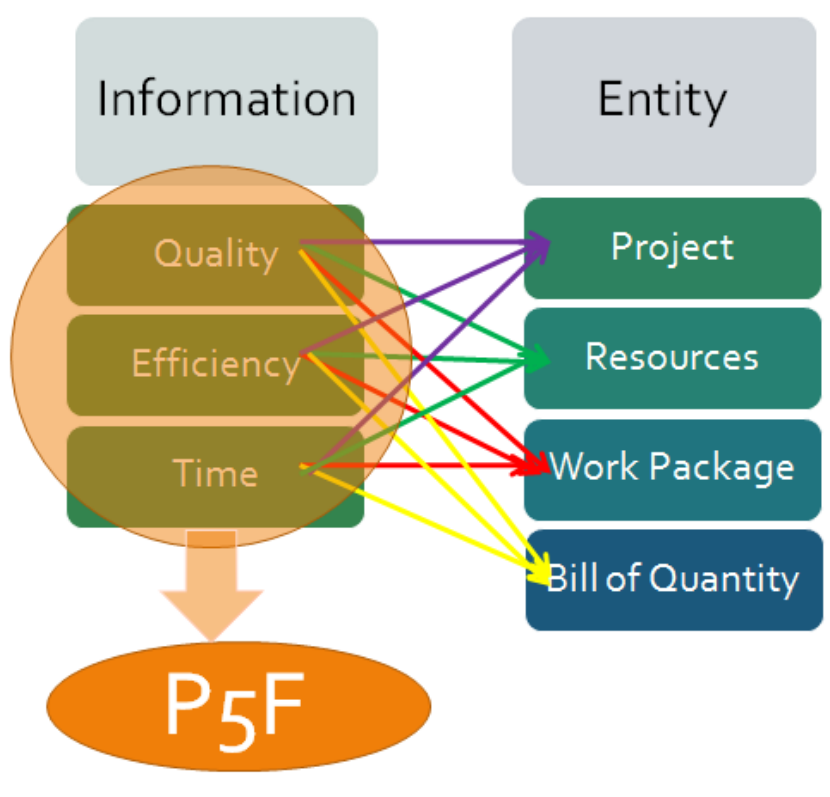

Gambar 1. Flowchart Metodologi Penelitian

3. Ke tiga macam informasi yang digunakan ini kemudian akan digunakan untuk menekan ke lima faktor yang terdapat dalam dapat ditekan untuk Porter's Five Forces. Porter's Five Forces disini digunakan sebagai tools untuk mengetahui posisi relatif perusahaan dan menganalisa kekuatan yang dapat ditekan dalam business process demi mencapai keunggulan bersaing.

4. Sebuah informasi membutuhkan banyak data dan sebuah data dapat menghasilkan banyak informasi. Data-data yang dibutuhkan untuk menhasilkan informasi ini harus dapat mendukung entity dari yang menghasilkan informasi yang akan digunakan perusahaan (Budiman, 2012)

5. Mendapatkan data yang dibutuhkan melalui Business Process yang terjadi dalam perusahaan fabrikasi baja. Metode yang digunakan adalah menguraikan proses fabrikasi menjadi Input (resources), activity (process) dan output (finish good). Dengan 
menggunakan hubungan dimana sebuah proses dalam fabrikasi baja adalah mengubah resources yang ada menjadi finish good melalui sebuah process.

6. Dari hasil analisa yang dilakukan sebuah data dapat menghasilkan banyak informasi, banyaknya data yang dikumpulkan ini kemudian disajikan melalui Entity Relationship Diagram (ERD) untuk mendapatkan informasi yang kemudian digunakan untuk mendapatkan Competitive Advantages melalui alat bantu Porter's Five Forces. Korelasi antara Data, Informasi dan Competitive Advantages dapat dilihat pada Gambar 2.

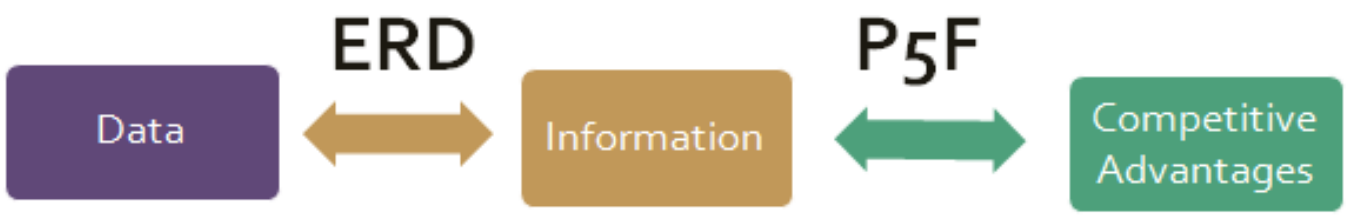

Gambar 2. Bagan Korelasi antara Data, Informasi dan Competitive Advantages

\section{ANALISA}

Analisa dilakukan dengan menentukan terlebih dahulu informasi apa yang dapat digunakan untuk mendapatkan keunggulan bersaing (Competitive Advantages) yang ingin dicapai oleh perusahaan fabrikasi baja. Pada penelitian ini akan digunakan tiga contoh informasi yaitu informasi mengenai mutu (Quality), efisiensi (Eficiency) dan waktu (time).

1. Mutu Produk (Quality)

Mutu dalam hal ini berkaitan dengan Quality yaitu Finish Good. Dengan menggunakan semantic model bahwa resource diproses oleh activity menjadi sebuah finish good. Maka finish good disini adalah hasil dari fabrication procces yang dirangkum dalam Bill of Quantity (BQ),dapat dikumpulkan data-data mengenai proses fabrikasi yang dapat dimulai dengan menentukan entity yang dibutuhkan yang dapat memberikan informasi mengenai quality. Dalam penelitian ini dipilih entity "Bill of Quantity".

Apabila strategi keunggulan mutu ini berhasil maka diharapkan perusahaan fabrikasi baja tersebut akan mendapatkan keuntungan sebagai market leader, sebagai sebuah perusahaan dengan kinerja diatas rata-rata dalam pasar yang dipilih (spesialis) yang tentunya akan menciptakan daya tarik tersendiri terhadap yang memprioritaskan keunggulan mutu produk, ini berarti perusahaan telah berhasil menekan rival dan customer.

2. Efisiensi (Eficiency)

Efisiensi produk berkaitan dengan proses produksi (fabrication dan erection) dapat dilakukan dalam hal biaya, Dalam hal efisiensi material, perusahaan seharusnya mempunyai database tentang kebutuhan material dari sebuah proyek yang akan datang dan database tentang konsumsi kebutuhan material proyek di masa lalu, hal ini akan memberikan keuntungan dimana sisa material baik raw material, maupun finish good dari proyek terdahulu dapat digunakan dan sesuai dengan kebutuhan proyek yang baru.

Melalui informasi yang berkaitan dengan efisiensi ini, maka perusahaan setidaknya telah menekan factor-faktor dalam Porter's Five Forces diantaranya:

a. Memberikan ketepatan proses fabrikasi maupun efisiensi harga yang lebih baik,

b. Business process lebih efektif dan efisien karena perusahaan mempunyai database yang lebih sistematis dan dapat dipertanggungjawabkan,

Maka perusahaan telah berhasil menekan rival, customer, supplier dan pendatang baru melalui efisiensi waktu dan biaya dari informasi yang digunakan.

3. Waktu (Time)

Informasi mengenai waktu disini adalah resource yang dapat berupa material, labour, equipment dan subcontractor, dimaksudkan agar perusahaan fabrikasi baja memiliki keunggulan berkaitan dengan informasi mengenai waktu. Untuk mendukung strategi keunggulan perusahaan menggunakan informasi mengenai waktu maka diperlukan 
informasi yang berisi tentang data yang berkaitan, antara lain: data proyek terdahulu dan data proyek yang sedang atau akan dihadapi.

Factor -faktor dalam Porter's Five Forces dapat ditekan melalui informasi yang berkaitan dengan waktu ini, diantaranya:

1. Perusahaan dapat memberikan harga penawaran yang competitive dibanding rival.

2. Perusahaan mampu menekan supplier untuk memberikan barang atau jasa dengan kualitas dan / atau harga yang lebih baik,

Karena besarnya lingkup proses fabrikasi baja dalam sebuah perusahaan fabrikasi baja, maka dalam penelitian ini data-data yang telah dikumpulkan kemudian diolah kedalam sebuah semantic model yang menggambarkan keseluruhan aktifitas dari proses fabrikasi baja. Modeling yang digunakan untuk menggambarkan proses fabrikasi baja yaitu membagi proses fabrikasi baja menjadi tiga entity yaitu: Resource, Activity, dan Finish Good ditambah sebuah entity baru yaitu Project.

Keempat entity ini dapat mengcapture keseluruhan proses fabrikasi dengan menetapkan entity relationship ketiganya dengan menggunakan hubungan dimana sebuah proses dalam fabrikasi baja adalah mengubah resources yang ada menjadi finish good melalui sebuah activity untuk maing-masing Project.

Seluruh kegiatan fabrikasi dapat diuraikan dengan sebuah permodelan sederhana dengan ketentuan:

1. Setiap Activity hanya boleh berkontribusi pada satu Finish Good

2. Satu Finish Good boleh terdiri dari beberapa Resource

Untuk menghasilkan suatu permodelan yang sistematis maka dalam pengolahan data yang ada, kita uraikan ke dalam 4 dimension (terlihat pada Gambar 3) untuk mempermudah proses pengolahan. Dimension ini akan membantu dalam mempermudah dalam memasukkan input data yang diperlukan dalam sistem permodelan, dimana output dari system permodelan yaitu penyajian data yang lebih mudah diterima oleh setiap individu dalam perusahaan fabrikasi

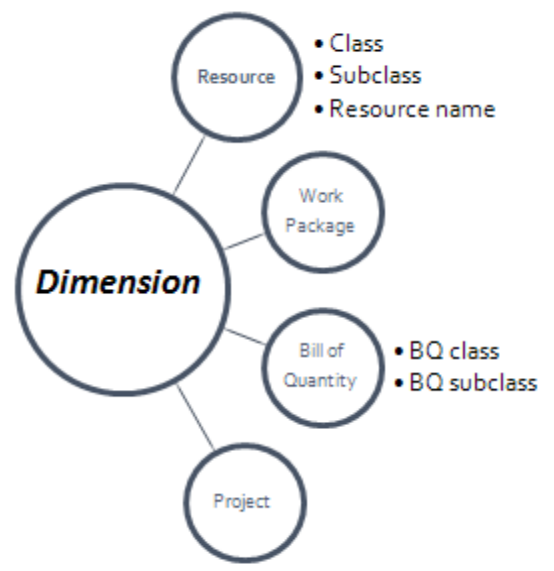

Gambar 3. Pembagian Dimension pada Sistem Permodelan

Proses Fabrikasi Baja

Dari setiap dimension yang telah kita tentukan, kita dapat melihat item apa saja yang terdapat didalamnya, kita juga dapat membagi setiap dimension tersebut ke dalam class atau subclass yang lebih kecil dan detail. Pada penelitian ini hanya dimension Work Package dan Project saja yang dibagi ke dalam 1 class, sementara dimension resource diturunkan 3 class tambahan , sementara dan Bill of Quantity diturunkan ke dalam 2 class tambahan. Gunadhi (2003) mengatakan bahwa proses fabrikasi baja terdiri dari proses shopdrawing, incoming 
material, marking, cutting, holing, assembling, welding, finishing, dan delivery, proses fabrikasi baja tersebut yang akan menjadi activity yang digunakan dalam workpackage pada penelitian ini.

Keempat entity ini mempunyai descriptor yang berisi tentang data- data yang dikumpulkan, besar descriptor tergantung dari informasi apa yang diperlukan oleh perusahaan baja, sehingga tidak ada batasan besarnya descriptor yang akan digunakan. Descriptor pada entity dalam proses fabrikasi baja dalam penelitian ini dapat dilihat pada Tabel 1.

\begin{tabular}{|l|l|l|l|l|}
\hline & \multicolumn{4}{|c|}{ Entity } \\
\cline { 2 - 5 } & Project & Resource & Workpackage & Bill of \\
Quantity
\end{tabular}

Tabel 1. Descriptor pada Entity dalam Proses Fabrikasi Baja

Masing-masing dari keempat entity ini harus mempunyai korelasi antar entity yaitu sebuah Entity Relationship Diagram (ERD), ERD ini yang kemudian nantinya menjadi mengubah antara data yang dikumpulkan menjadi sebuah informasi yang bertujuan untuk mendapatkan keunggulan bersaing dalam sebuah perusahaan fabrikasi baja.

Dengan menggunakan hubungan antara masing-masing entity ini dapat kita buat menjadi sebuah Entity Relationship Diagram (ERD), seperti terlihat pada Gambar 4.

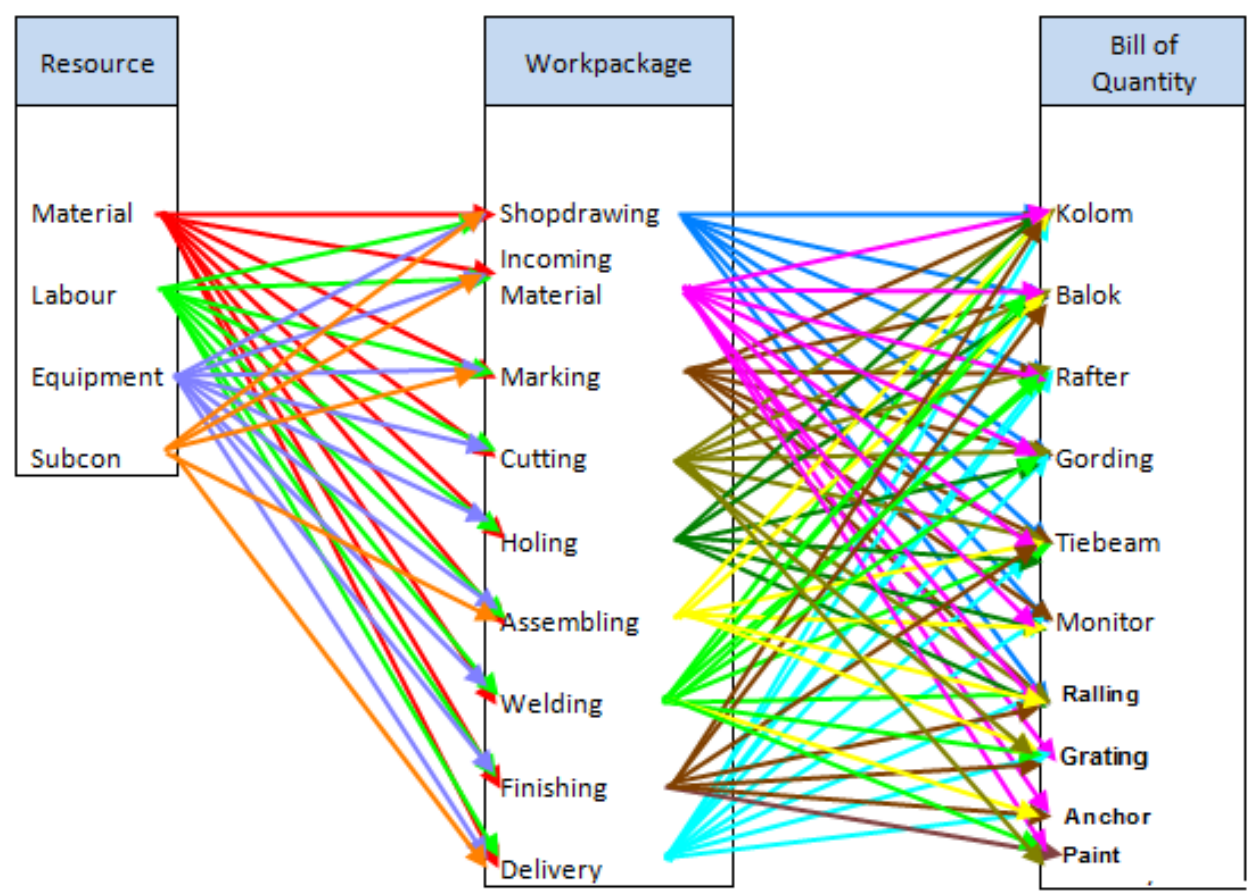

Gambar 4 Entity Relationship Diagram diantara Entity Project Resource, Workpackage dan Bill of Quantity 
Dari Gambar 4. dengan menggunakan Entity Relationship Diagram, perusahaan fabrikasi baja dapat menemukan kerangka berpikir yang baik tentang bagaimana strategi memanfaatkan informasi. Strategi ini didapatkan dengan menggali semua data yang terdapat di dalam business process untuk kemudian dipakai sebagai atribut pendukung entity yang akan dipakai oleh perusahaan fabrikasi baja. Entity ini yang akan dicari korelasinya menggunakan Entity Relationship Diagram yang dapat memberikan semua informasi berkaitan dengan business process.

Untuk membantu mengumpulkan data yang dibutuhkan setiap entity yang diperlukan untuk menghasilkan informasi dalam business process fabrikasi baja, maka dapat digunakan sebuah software. Software ini nantinya berguna untuk mempermudah proses input, analysis dan output pada business process fabrikasi baja. Pada penelitian ini proses pengolahan informasi dari input hingga menjadi output data yang ada dalam proses fabrikasi baja digunakan software sederhana Visual FoxPro. Tampilan hasil output data dari proses pengolahan data yang digunakan pada penelitian ini dapat dilihat pada Gambar 5.

\begin{tabular}{|c|c|c|c|c|c|c|c|}
\hline & \multirow[b]{2}{*}{ rs_clnnm } & \multirow[b]{2}{*}{ - rs_scl_nm } & \multirow[b]{2}{*}{ res_nm } & \multirow[b]{2}{*}{ res_unt } & \multirow{3}{*}{\begin{tabular}{|l|} 
Wp_name \\
Assemblino Frection
\end{tabular}} & \multicolumn{2}{|l|}{ Data } \\
\hline \multirow{2}{*}{$\begin{array}{l}\text { project } \\
\text { P01 }\end{array}$} & & & & & & \multicolumn{2}{|c|}{ Sum Of pln aty Sum Of pln cost } \\
\hline & \multirow[t]{22}{*}{ E Equipment } & \multirow[t]{12}{*}{ EHeavy } & \multirow[t]{2}{*}{ G Mobile Crane 80 Ton } & hari & & 9 & $63,000,000$ \\
\hline & & & & hari Total & & 9 & $63,000,000$ \\
\hline & & & \multirow[t]{2}{*}{$\Xi$ On Fabrication.Crane 3 Ton } & hari & Assembling (Fabr) & 16 & 640,000 \\
\hline & & & & hari Total & & 16 & 640,000 \\
\hline & & & \multirow[t]{6}{*}{$\exists$ On Fabrication.Cutting llachine } & hari & Cutting (Fabr) & 4 & 320,000 \\
\hline & & & & \begin{tabular}{|l|} 
hari Total \\
\end{tabular} & & 4 & 320,000 \\
\hline & & & & & Cutting (Fabr) & 1 & 80,000 \\
\hline & & & & har Total & & 1 & 80,000 \\
\hline & & & & \begin{tabular}{|l|} 
hari \\
\end{tabular} & Cutting (Fabr) & 29 & $2,320,000$ \\
\hline & & & & hari Total & & 29 & $2,320,000$ \\
\hline & & & \multirow[t]{2}{*}{$\exists$ On Fabrication. Holling Machine } & hari & Holling (Fabr) & 23 & 253,000 \\
\hline & & & & \begin{tabular}{|l|l|} 
hari Total \\
\end{tabular} & & 23 & 253,000 \\
\hline & & \multirow[t]{10}{*}{$\theta$ Light } & \multirow[t]{2}{*}{ G Mesin Gerinda Besar } & hari & Cutting (Erection) & 4 & 80,000 \\
\hline & & & & \begin{tabular}{|l|l|} 
hari Total \\
\end{tabular} & & 4 & 80,000 \\
\hline & & & \multirow[t]{2}{*}{ - Mesin Gerinda Kecil } & hari & Cutting (Erection) & 5 & 35,000 \\
\hline & & & & \begin{tabular}{|l|} 
hari Total \\
\end{tabular} & & 5 & 35,000 \\
\hline & & & \multirow[t]{3}{*}{ GMesin Las } & hari & Welding (Erection) & 8 & $1,280,000$ \\
\hline & & & & & Welding (Fabr) & 32 & $5,120,000$ \\
\hline & & & & hari Total & & 40 & $6,400,000$ \\
\hline & & & \multirow[t]{3}{*}{ GTrafo Mesin Las } & hari & Welding (Erection) & 8 & $1,360,000$ \\
\hline & & & & & Welding (Fabr) & 32 & $5,440,000$ \\
\hline & & & & hari Total & & 40 & $6,800,000$ \\
\hline & \multirow{7}{*}{\begin{tabular}{|l} 
Equipment Total \\
ELabour
\end{tabular}} & & & & & 171 & $79,928,000$ \\
\hline & & \multirow[t]{6}{*}{ EErection } & \multirow[t]{6}{*}{$E$ Mandor Muntar } & hari & Assembling (Erection) & 31 & $1,240,000$ \\
\hline & & & & & Cutting (Erection) & 5 & 200,000 \\
\hline & & & & & Holling (Erection) & 2 & 80,000 \\
\hline & & & & & Welding (Erection) & 6 & 240,000 \\
\hline & & & & \begin{tabular}{|l|l|} 
hari Total \\
\end{tabular} & & 44 & $1,760,000$ \\
\hline & & & & hari & Assembling (Erection) & 19 & $1,330,000$ \\
\hline
\end{tabular}

Gambar 5. Hasil Output Data yang Memberikan Informasi dari Project, Workpackage dan Bill of Quantity Dimension

Pada Gambar 5. ditunjukkan contoh hasil output dengan penyajian informasi mengenai proyek PO1, terlihat item-item yang terlibat dalam proyek PO1 yaitu equipment yang terdapat didalamnya, baik alat kerja berat (heavy), maupun alat kerja ringan (light) yang dikombinasikan dengan workpackage. Dapat terlihat total cost dari proyek PO1 berkaitan dengan resource yang digunakan pada masing-masing workpackage.

Dengan mempunyai informasi yang tersaji dalam Entity Relationship Diagram (ERD), maka perusahaan dapat menggali keunggulan apa saja yang dapat dihasilkan dari penerapan informasi. Keunggulan bersaing didapatkan dengan menggunakan cara menekan ke lima faktor yang ada di dalam Porter's Five Forces, Porter's Five Forces sendiri dalam penelitian ini berguna sebagai landasan utama pemanfaatan informasi dalam sebuah perusahaan fabrikasi baja untuk mendapatkan keunggulan bersaing. 


\section{KESIMPULAN}

Kesimpulan yang dapat diambil dalam penelitian ini adalah:

1. Dalam penelitian ini dihasilkan penggunaan informasi dalam perusahaan fabrikasi baja yang dibutuhkan untuk mendapatkan keunggulan bersaing yaitu dengan menggunakan informasi keunggulan mutu produk (quality), efisiensi biaya (efficiency), dan waktu (time).

2. Entity Relationship Diagram (ERD) dalam perusahaan fabrikasi baja menggunakan entityentity yang terlibat di dalamnya, entity ini terdiri dari Project, Resource, Workpackage, dan Bill of Quantity. Entity Relationship Diagram (ERD) yang digunakan dalam penelitian ini yaitu dengan menggunakan Workpackage dalam sebuah Project, maka perusahaan fabrikasi baja dapat mengubah Resource menjadi Bill of Quantity.

3. Informasi keunggulan mutu produk (quality) dapat dicapai dengan mengumpulkan data berkaitan dengan Entity Bill of Quantity. Data mengenai Entity Bill of Quantity berkaitan dengan kualitas hasil pekerjaan yang terdapat di dalam BoQ, berupa rating hasil fabrikasi, tingkat kecacatan hasil fabrikasi dan tingkat kepuasan pelanggan terhadap hasil fabrikasi.

4. Informasi efisiensi biaya (efficiency) dapat dicapai dengan mengumpulkan data berkaitan dengan Entity Workpackage. Data mengenai Entity Workpackage berkaitan dengan stock dan waste dari proses fabrikasi yang terjadi sebelumnya.

5. Informasi waktu (time) dapat dicapai dengan mengumpulkan data berkaitan dengan Entity Resource. Data mengenai Entity Resource berkaitan dengan kecepatan penyediaan material maupun tingkat kualitas dari labour, equipment dan subcon.

\section{DAFTAR REFERENSI}

Budiman, J. (2012). "Catatan Kuliah Competitive Advantages Through I.T". Program Pascasarjana Manajemen Konstruksi Universitas Kristen Petra Surabaya.

Gunadhi, M. (2003). "Sistem Perencanaan dan Pengendalian Kualitas Proses Fabrikasi Komponen Struktur Baja", Thesis. Universitas Kristen Petra Surabaya.

Porter, M. E. (1998). "Competitive Strategy Technique for Analyzing Industries and Competitors". 